\title{
ANALISIS KADAR HYDRAZINE DALAM BOILER FEED WATER (BFW) MENGGUNAKAN METODE SPEKTROFOTOMETER UV-VIS DI PT PUPUK ISKANDAR MUDA
}

\author{
Nur Harliananda ${ }^{1^{*}}$, dan Rahmatul Fajri ${ }^{1}$ \\ ${ }^{1}$ Program Studi Kimia Fakultas Teknik Universitas Samudra \\ Jl. Meurandeh, Langsa Aceh 24416, Indonesia \\ * Corresponding author:_nandanur1905@gmail.com
}

\begin{abstract}
ABSTRAK
Telah dilakukan pengujian tentang analisis kadar hydrazine dalam Boiler Feed Water dengan menggunakan metode spektrofotometer UV-Vis di PT Pupuk Iskandar Muda. Tujuan khusus dari Kerja Praktek ini adalah untuk mengetahui kadar hydrazine pada Boiler Feed Water. Pengujian ini dilakukan dengan menggunakan metode spektrofotometer UV-Vis dengan panjang gelombang $455 \mathrm{~nm}$ dan kuvet $20 \mathrm{~mm}$. Berdasarkan analisis terhadap air Boiler Feed Water menunujukkan bahwa kadar hydrazine pada pengambilan sampel 1 sampei 6 masih dalam tetapan parameter. Sedangkan pada pengambilan sampel 7 sampai 14 telah melewati batas maksimum. Maka dari itu yang harus dilakukan adalah mengurangi penginjeksian hydrazine dan melakukan penambahan air demin ke dalam sistem Boiler Feed Water.
\end{abstract}

Kata Kunci : Hydrazine, Boiler Feed Water, Spektrofotometer, Air Demin.

\section{PENDAHULUAN}

PT Pupuk Iskandar Muda merupakan sebuah perusahaan yang bergerak dalam bidang industri pupuk urea. PT Pupuk Iskandar Muda terletak di wilayah Zona Industri Lhokseumawe (ZILS) $\pm 250 \mathrm{~km}$ sebelah Timur Banda Aceh, di Krueng Geukueh, Kecamatan Dewantara, Kabupaten Aceh Utara, Provinsi Aceh, Indonesia. PT Pupuk Iskandar Muda memiliki tanah seluas $323 \mathrm{Ha}$, dengan perincian area $162 \mathrm{Ha}$ untuk keperluan pabrik dan pelabuhan, serta $161 \mathrm{Ha}$ untuk kebutuhan perumahan dan sarana fasilitasnya. PT Pupuk Iskandar Muda dianggap sangat mendukung dalam penerapan dan pengembangan ilmu, khususnya ilmu kimia. IImu kimia adalah suatu ilmu yang mempelajari tentang susunan, struktur, sifat dan perubahan materi. IImu kimia yang diterapkan di PT Pupuk Iskandar Muda mempunyai peranan penting untuk membantu mengolah produk yang dihasilkan. Contohnya dalam menganalisis banyaknya kadar hydrazine yang terdapat pada air boiler yang akan digunakan untuk memproduksi pupuk urea.

Boiler merupakan suatu wadah tertutup dimana panas pembakaran dialirkan ke air hingga terbentuk air panas. Air panas pada tekanan tertentu kemudian digunakan untuk mengalirkan panas kesuatu proses. Beberapa jenis boiler yang sering digunakan yaitu Fire
Tube Boiler dan Water Tube Boiler. Pada Fire Tube Boiler, gas panas melewati pipa-pipa dan Boiler Feed Water yang terdapat dalam shell untuk diubah menjadi steam. Sedangkan Water Tube Boiler, Boiler Feed Water mengalir melalui pipa-pipa masuk ke dalam drum. Pipa-pipa penghubung yang mengalirkan air tersebut terbuat dari logam besi $(\mathrm{Fe})$. Air yang mengalir harus bebas dari mineral-mineral dan zat pengotor lainnya yang dapat menimbulkan efisiensi kerja dari boiler. Maka dari itu, sistem Boiler Feed Water harus memenuhi spesifikasi yang telah ditentukan agar tidak terdapat masalah pada pengoperasian boiler (Fatimura, 2015).

Korosi adalah suatu proses kerusakan logam oleh suatu reaksi kimia atau elektrokimia sebagai akibat adanya interaksi antara logam dengan lingkungannya (Utomo dan Alva, 2017). Korosi dapat terjadi dikarenakan adanya oksigen yang terdapat di dalam air yang disebut sebagai dissolve oxygen atau oksigen terlarut. Dissolve oxygen adalah konsentrasi gas oksigen yang terlarut dalam air, bersumber dari aktifitas fotosintesis fitoplankton dan difusi oksigen, sehingga pada lapisan permukaan perairan kandungan oksigen terlarut akan lebih tinggi. Hal tersebut disebabkan adanya beberapa faktor antara lain faktor alami maupun faktor aktifitas antropogenik, yaitu dengan adanya perubahan 
penggunaan lahan didukung fluktuasi perubahan lingkungan dengan adanya monsoon. Kondisi ekologis tersebut dikhawatirkan dapat mempengaruhi kandungan oksigen yang terlarut (Dewi, et.al, 2017).

Hampir semua sektor industri memiliki permasalahan dengan korosi, seperti industri perhubungan, industri pertambangan dan energi, industri pertanian, industri logam, dan lain sebagainya. Permasalahan yang muncul seperti kerusakan, umur pakai barang yang tidak memenuhi harapan hingga pada faktor keamanan yang tidak memadai. Korosi dalam prosesnya tidak dapat dihentikan, namun laju dari proses terjadinya korosi dapat dikurangi dengan cara pemakaian inhibitor (Sulistyaningsih dan Lestari, 2018).

Adapun inhibitor yang dapat mengurangi adanya korosi adalah hydrazine. Hydrazine merupakan suatu senyawa hydro nitrogen yang memiliki rumus molekul $\mathrm{N}_{2} \mathrm{H}_{4}$ dan dapat ditemui dalam bentuk larutan. Hydrazine adalah reduktor kuat dan banyak digunakan dalam bidang pengolahan air, khususnya dalam sistem air umpan boiler (Boiler Feed Water) sebagai pengikat oksigen (Sitompul, 2005). Senyawa hydrazine memiliki sifat kimia sebagai reduktor yang kuat karena hydrazine berperan sebagai pendonor gugus hidrogen yang dapat mereduksi ikatan rangkap menjadi ikatan tunggal melalui reaksi hidrogenasi. Hydrazine memiliki keunggulan lain, yaitu memiliki tingkat korosi yang rendah (Vachlepi, 2018).

Kadar hydrazine yang berlebihan mempunyai dampak yang tidak baik dalam produksi pupuk urea. Berdasarkan hal tersebut maka penulis mencoba untuk menganalisis kadar hydrazine dalam Boiler Feed Water (BFW) menggunakan metode spektrofotometer UV-Vis di PT Pupuk Iskandar Muda.

\section{METODOLOGI PENELITIAN}

Alat

Alat yang digunakan adalah labu ukur 50 $\mathrm{ml}$, pipet ukur, pipet volume dan spektrofotometer UV-Vis Shimadzu 1601.

\section{Bahan}

Bahan yang digunakan adalah larutan standar hydrazine $1 \mathrm{ppm}$, asam klorida $(\mathrm{HCl})$, larutan Para-Dimethylamino Benzaldehida $\left(\mathrm{C}_{9} \mathrm{H}_{11} \mathrm{NO}\right) 2 \%$, dan sampel air Boiler Feed Water.

\section{Prosedur Kerja Prosedur Kalibrasi}

Larutan standar hydrazine $1 \mathrm{ppm}$ dibuat dengan variasi konsentrasi $(0,08 ; 0,16 ; 0,24$; 0,32 ; dan 0,40 ) ppm dengan memipet larutan standar sebanyak 2, 4, 6, 8, $10 \mathrm{~mL}$. Untuk larutan blanko, digunakan $25 \mathrm{ml}$ air demin lalu dimasukkan dalam labu ukur $50 \mathrm{ml}$. Kemudian ditambahkan pereaksi $\mathrm{HCl}$ sebanyak $2,5 \mathrm{ml}$ dan pereaksi $\mathrm{C}_{9} \mathrm{H}_{11} \mathrm{NO} 2 \%$ sebanyak $5 \mathrm{ml}$ disetiap labu ukur. Lalu, dihimpitkan dengan air demin sampai tanda batas dan dikocok hingga homogen, didiamkan selama 10 menit untuk pengembangan warna. Selanjutnya larutan standar diuji dengan menggunakan spektrofotometer UV-Vis dengan panjang gelombang $455 \mathrm{~nm}$ dan kuvet $20 \mathrm{~mm}$. Dihitung faktor kalibrasinya dengan menggunakan rumus

$$
\text { Faktor kalibrasi }=\frac{\text { Konsentrasi standar }}{\text { Absorbansi standar }}
$$

\section{Prosedur Analisa}

Sampel dan air demin dipipet sebanyak 25 $\mathrm{ml}$ lalu dimasukkan dalam labu ukur $50 \mathrm{ml}$. Kemudian ditambahkan pereaksi $\mathrm{HCl}$ sebanyak $2,5 \mathrm{ml}$ dan pereaksi $\mathrm{C}_{9} \mathrm{H}_{11} \mathrm{NO} 2 \%$ sebanyak $5 \mathrm{ml}$ disetiap labu ukur. Lalu, dihimpitkan dengan air demin sampai tanda batas dan dikocok hingga homogen, didiamkan selama 10 menit untuk pengembangan warna. Selanjutnya larutan standar diuji dengan menggunakan spektrofotometer UV-Vis dengan panjang gelombang $455 \mathrm{~nm}$ dan kuvet $20 \mathrm{~mm}$. Dihitung faktor kurva kalibrasinya dengan menggunakan rumus :

$$
\mathrm{N}_{2} \mathrm{H}_{4}, \mathrm{ppm}=\text { Abs } \times \text { Faktor Kalibrasi }
$$

\section{HASIL DAN PEMBAHASAN}

Berdasarkan pengamatan terhadap perhitungan kalibrasi hydrazine dan hasil analisis terhadap Boiler Feed Water yang telah dilakukan, maka diperoleh hasil berupa data absorbansi dan konsentrasi tiap sampel seperti pada Tabel 1. berikut ini : 
Tabel 1. Kalibrasi Larutan Standar Baku Hydrazine Dengan Menggunakan Spektrofotometer UV-Vis

\begin{tabular}{|c|c|c|}
\hline Sampel & Abs & $\mathbf{K}$ (ppm) \\
\hline Blanko & 0 & 0 \\
\hline 1 & 0,144 & 0,08 \\
\hline 2 & 0,290 & 0,16 \\
\hline 3 & 0,430 & 0,24 \\
\hline 4 & 0,565 & 0,32 \\
\hline 5 & 0,708 & 0,40 \\
\hline
\end{tabular}

Tabel 2. Hasil Analisa Boiler Feed Water

\begin{tabular}{|c|c|c|c|}
\hline Tanggal & PS & Abs & K (ppm) \\
\hline \multirow{4}{*}{$\begin{array}{c}17 \\
\text { Januari } \\
2020\end{array}$} & \multirow{2}{*}{1} & 0,184 & 0,1029 \\
\hline & & 0,183 & 0,1024 \\
\hline & \multirow{2}{*}{2} & 0,127 & 0,0710 \\
\hline & & 0,127 & 0,0710 \\
\hline \multirow{4}{*}{$\begin{array}{c}20 \\
\text { Januari } \\
2020\end{array}$} & \multirow{2}{*}{3} & 0,131 & 0,0733 \\
\hline & & 0,134 & 0,0750 \\
\hline & \multirow{2}{*}{4} & 0,120 & 0,0671 \\
\hline & & 0,123 & 0,0688 \\
\hline \multirow{4}{*}{$\begin{array}{c}21 \\
\text { Januari } \\
2020\end{array}$} & \multirow{2}{*}{5} & 0,127 & 0,0710 \\
\hline & & 0,131 & 0,0733 \\
\hline & \multirow{2}{*}{6} & 0,135 & 0,0755 \\
\hline & & 0,132 & 0,0738 \\
\hline \multirow{4}{*}{$\begin{array}{c}22 \\
\text { Januari } \\
2020\end{array}$} & \multirow{2}{*}{7} & 0,240 & 0,1342 \\
\hline & & 0,243 & 0,1359 \\
\hline & \multirow{2}{*}{8} & 0,244 & 0,1365 \\
\hline & & 0,255 & 0,1426 \\
\hline \multirow{4}{*}{$\begin{array}{c}27 \\
\text { Januari } \\
2020\end{array}$} & \multirow{2}{*}{9} & 0,541 & 0,3026 \\
\hline & & 0,547 & 0,3060 \\
\hline & \multirow{2}{*}{10} & 0,501 & 0,2802 \\
\hline & & 0,506 & 0,2830 \\
\hline \multirow{4}{*}{$\begin{array}{c}28 \\
\text { Januari } \\
2020\end{array}$} & \multirow{2}{*}{11} & 0,5040 & 0,2819 \\
\hline & & 0,5118 & 0,2863 \\
\hline & \multirow{2}{*}{12} & 0,5127 & 0,2868 \\
\hline & & 0,5135 & 0,2872 \\
\hline \multirow{4}{*}{$\begin{array}{c}29 \\
\text { Januari } \\
2020\end{array}$} & \multirow{2}{*}{13} & 0,0678 & 0,0380 \\
\hline & & 0,0683 & 0,0382 \\
\hline & \multirow{2}{*}{14} & 0,3960 & 0,2215 \\
\hline & & 0,4141 & 0,2316 \\
\hline \multicolumn{3}{|c|}{ Konsentrasi Rata-Rata (ppm) } & 0,1542 \\
\hline
\end{tabular}

Catatan :

PS : Pengambilan Sampel

Abs : Absorbansi

K : Konsentrasi (ppm)
Rumus:

Perhitungan Faktor Kalibrasi :

Faktor kalibrasi $=\frac{\text { Konsentrasi standar }}{\text { Absorbansi standar }}$

Perhitungan Faktor Kalibrasi Rata-Rata :

$\mathrm{FK}$ rata-rata $=\frac{\mathrm{Fk}_{1}+\mathrm{Fk}_{2}+\mathrm{Fk}_{3}+\mathrm{Fk}_{4}+\mathrm{Fk}_{5}}{5}$

Perhitungan Konsentrasi Sampel :

$\mathrm{N}_{2} \mathrm{H}_{4}, \mathrm{ppm}=$ Abs $\times$ Faktor Kalibrasi

Pengujian yang dilakukan menggunakan Boiler Feed Water sebagai sampel yang diambil sehari 2 kali selama 7 hari. Uji kuantitatif ini bertujuan untuk mengetahui kandungan kadar hydrazine yang terdapat pada Boiler Feed Water. Diuji menggunakan spektrofotometer dengan menggunakan cuvet cell sebesar $20 \mathrm{~mm}$ dan panjang gelombang sebesar $455 \mathrm{~nm}$.

Hydrazine merupakan salah satu jenis inhibator korosi terhadap logam dimana proses inhibisinya secara efektif melalui penurunan konsentrasi oksigen terlarut serta membentuk senyawa komplek dengan ion logam yang melapisi permukaan logam. Reaksi hydrazine dengan oksigen menghasilkan air dan gas nitrogen. Sedangkan reaksi hydrazine dengan logam menghasilkan hydrazine yang telah berikatan dengan logam $\left(\mathrm{Fe}\left(\mathrm{N}_{2} \mathrm{H}_{4}\right)_{3}{ }^{2+}\right)$. Hasil reaksi berupa air $\left(\mathrm{H}_{2} \mathrm{O}\right)$ pada reaksi hydrazine dengan oksigen murni akan masuk kedalam storage water tank sedangkan nitrogen $\left(\mathrm{N}_{2}\right)$ akan dibuang ke atmosfer. Laju reaksi hydrazine dengan oksigen tidak begitu cepat, tetapi dapat ditingkatkan dengan penambahan katalis. Berdasarkan reaksi diatas, kebutuhan hydrazine untuk menyingkirkan $1 \mathrm{ppm} \mathrm{O}_{2}$ adalah $1 \mathrm{ppm}$.

Menurut Research Commitee on Steam \& Water in Thermal Power System, kadar oksigen dalam Boiler Feed Water untuk boiler tekanan tinggi disarankan kurang dari $7 \mathrm{ppb}$ (trace). Penghilangan oksigen dalam Boiler Feed Water dapat dilakukan secara fisika dan kimia. Untuk mencapai kadar oksigen yang sangat rendah (kurang dari $7 \mathrm{ppb}$ ), oksigen dapat dihilangkan dengan menggunakan bahan kimia.

Berdasarkan data yang diperoleh pada Tabel 1. terhadap kalibrasi hydrazine dengan variasi konsentrasi 0,$08 ; 0,16 ; 0,24 ; 0,32$; dan 0,40 ppm yang kemudian diukur absorbansinya pada panjang gelombang $455 \mathrm{~nm}$ dan cuvet cell 
$20 \mathrm{~mm}$. Berdasarkan hasil pengukuran absorbansi yang dihasilkan berturut-turut yaitu 0,$144 ; 0,290 ; 0,430 ; 0,565$; dan 0,708 yang dapat dilihat pada Gambar 3.1. Berdasarkan kurva baku larutan standar hydrazine menunjukkan bahwa semakin tinggi konsentrasi larutan standar hydrazine maka semakin tinggi pula absorbansinya. Begitu pula sebaliknya, semakin kecil konsentrasi hydrazine maka semakin kecil pula absorbansinya.

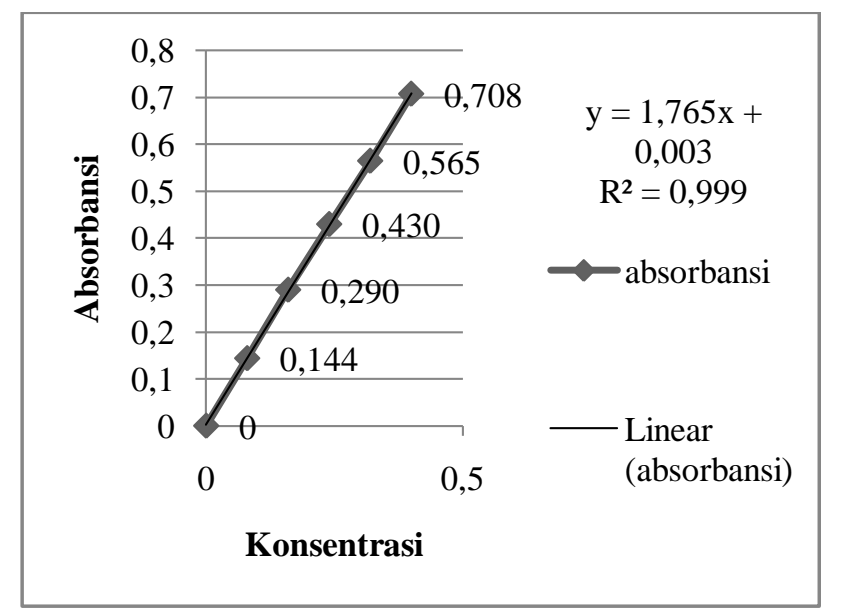

\section{Gambar 1. Kurva Baku Larutan Standar Hydrazine}

Berdasarkan data analisis terhadap hydrazine pada Boiler Feed Water (Tabel 2.) menunjukkan bahwa konsentrasi pada tiap pengambilan sampel, yaitu tepatnya pada pengambilan sampel 1 sampai 6 terlihat bahwa konsentrasi yang dihasilkan sesuai dengan parameter yang telah ditetapkan oleh Laboratorium Utility PT Pupuk Iskandar Muda, dimana kadar hydrazine pada Boiler Feed Water yang disarankan yaitu dari 0,07 ppm-0,1 ppm. Sedangkan pada pengambilan sampel 7 sampai 14 kadar hydrazine pada sistem Boiler Feed Water telah melewati ketetapan parameter, hal tersebut menujukkan bahwa hydrazine yang terdapat pada sistem Boiler Feed Water tidak stabil. Hydrazine yang tidak stabil dikarenakan berlebihnya kadar hydrazine yang diinjeksi ke sistem Boiler Feed Water. Hal tersebut dapat diantisipasi dengan mengurangi penginjeksian hydrazine dan melakukan penambahan air demin ke dalam sistem Boiler Feed Water.

\section{KESIMPULAN}

Berdasarkan hasil pengamatan terhadap analisis kadar hydrazine dalam Boiler Feed Water (BFW) menggunakan metode spektrofotometer UV-Vis di PT Pupuk Iskandar Muda maka dapat disimpulkan bahwa faktor kalibrasi spektrofotometer untuk standar hydrazine adalah sebesar 0,55936 serta kadar hydrazine dalam Boiler Feed Water yang dianalisis pada Januari 2020 menunjukkan hasil dengan rata-rata sebesar 0,1542 ppm. Namun, kandungan hydrazine yang ideal sesuai dengan pabrik adalah 0,07 ppm - 0,1 ppm. Kadar hydrazine yang terdapat pada boiler sudah berlebihan dari yang ditetapkan, maka dari itu yang harus dilakukan adalah mengurangi penginjeksian hydrazine dan melakukan penambahan air demin ke dalam sistem Boiler Feed Water.

\section{UCAPAN TERIMA KASIH}

Penulis mengucapkan terima kasih kepada PT Pupuk Iskandar Muda sebagai tempat penelitian. Penulis juga berterima kasih kepada Ibu Rahmatul Fajri, S.Pd., M.Si atas diskusinya yang bermanfaat. Serta kepada kedua orangtua penulis yang telah mendukung penulis.

\section{REFERENSI}

Dewi, R., Zainuri, M., Anggoro, S., dan Winanto, T. 2017. Laju Penurunan Kandungan Oksigen Terlarut Kawasan Laguna Segara Anakan. Jurnal Harpodon Borneo. 10:1. 28-36.

Fatimura, M. 2015. Tinjauan Teoritis Permasalahan Boiler Feed Water Pada Pengoperasian Boiler Yang Dipergunakan Dalam Industri. Jurnal Media Teknik. 12:1. 24-32.

Putri, L.E. 2017. Penentuan Konsentrasi Senyawa Berwarna KMnO4 Dengan Metoda Spektroskopi UV Visible. Natural Science Journal. 3:1. 391-398.

Sitompul, J.P. 2005. Studi Produksi Hidrazin VIA Proses Urea. Reaktor. 9:1. 20-25.

Sulistyaningsih, E., dan Lestari, N. 2018. Pengaruh Komposisi Material Komposit PAni-TiO2 Yang Disintesis secara Elektrodeposisi Terhadap Laju Korosi Pada Baja Karbon Rendah. Fullerene Journ. Of Chem. 3:2. 52-57.

Susanti, L., Setyowati, M., Widodo, S., danSetiawati, A. 2018. Uji Kadar Nitrit Pada Daging Burger Kota Bandar Lampung Menggunakan Spektrofotometer UV-Vis. Jurnal Farmasi Lampung. 7:1. 2732. 
Utomo, R.S.B., dan Alva, S. 2017. Studi dan Karakterisasi Laju Korosi Logam Aluminium Dengan Pelapisan Membran Sol-Gel. Jurnal Teknik Mesin. 6:3. 191198.

Vachlepi, A. 2018. Produksi Karet SIR 20CV Menggunakan Formula Hidrazin Hidrat dan Ammonium Sulfat Sebagai Aditif. Jurnal Dinamika Penelitian Industri. 29:1. 1-11. 